\title{
Extreme sulfur isotope fractionation in the seafloor hydrothermal deposit of the Okinawa Trough revealed by SIMS in-situ analysis
}

\author{
TATSUO NOZAKI ${ }^{1,2,3,4}$, TOSHIRO NAGASE ${ }^{5}$, TAKAYUKI
} USHIKUBO $^{6}$, KENJI SHIMIZU ${ }^{6}$, JUN-ICHIRO ISHIBASHI ${ }^{7}$ AND CK16-05 CRUISE MEMBERS

${ }^{1}$ JAMSTEC/SRRC, ${ }^{2}$ Univ. of Tokyo, ${ }^{3}$ Kobe Univ., ${ }^{4}$ Chiba Tech, ${ }^{5}$ Tohoku Univ., ${ }^{6} \mathrm{JAMSTEC} / \mathrm{KCC},{ }^{7} \mathrm{Kyushu}$ Univ.

*E-mail address: nozaki@jamstec.go.jp

Seafloor hydrothermal deposit is mainly composed of pyrite, sphalerite, galena and chalcopyrite with other sulfide/sulfate minerals. Sulfur in the main constituent sulfide minerals has been generally derived from mixture of magmatic and seawater sulfur [1,2]. Here, we report an extreme sulfur isotope fractionation in pyrite due to the bacterial sulfate reduction from the two modern seafloor hydrothermal deposits of the Iheya-North Knoll and Izena Hole in the Okinawa Trough revealed by the SIMS analysis.

We used drill core samples of the Iheya-North Knoll and Izena Hole obtained from the IODP Exp. 331 and cruise CK16-05. Based on the visual core descriptions, the sulfiderich drill core sample beneath a sediment of the Izena Hole has a pyrite texture of framboid, colloform and euhedral along with maturation processes. Sulfur isotopes $\left(\delta^{34} S\right)$ of the framboidal, colloform and euhedral pyrites are ranging from 38.91 to $-2.84 \%$ o $(-17.28 \pm 10.21 \%$ o $),-13.63$ to $-2.96 \%$ o $(-7.36$ $\pm 2.47 \%$ ) and -13.43 to $-3.80 \%$ o $(-6.78 \pm 2.69 \%$ ), respectively. The framboidal pyrite in the pumice above the subseafloor sulfide layer exhibits a narrow and light $\delta^{34} \mathrm{~S}$ from -34.31 to $37.13 \%$. Moreover, the subseafloor sulfide layer was formed by replacement mineralization of a porous pumice layer based on the microscopic observations [3]. Similar sulfur isotope fractionation was observed at the flank of the mound in the Iheya-North Knoll whose framboidal and euhedral pyrite grains have $\delta^{34} \mathrm{~S}$ ranging from -38.03 to $-10.35 \%$ o $(-28.25 \pm$ $9.84 \%$ o $)$ and +0.36 to $+3.86 \%$ o $(+2.85 \pm 1.11 \%)$. Combined with the recently reported extreme $\delta^{34} \mathrm{~S}$ fractionation in the Spanish and American VMS deposits [4,5], replacement mineralization beneath a seafloor using framboidal pyrites derived from bacterial sulfate reduction plays a key role to form a large-scale seafloor hydrothermal deposit.

[1] Ohmoto (1996) Ore Geol. Rev., 10, 135-177. [2] Shanks (2001) Rev. Mineral. Geochem., 43, 469-525. [3] Nozaki et al. (2018) AGU Fall Meeting Abstr. [4] Velasco-Acebes et al. (2019) Mineral. Deposita, 54, 913-934. [5] Slack et al. (2019) Chem. Geol., 513, 226-238. 